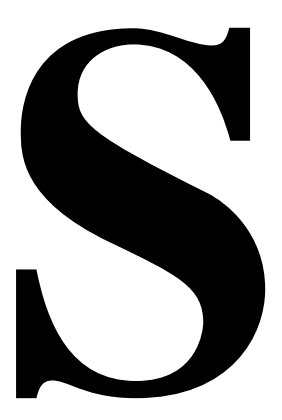

\title{
EMANTIC PARAMETERS TO MANAGE AN INNOVATION NETWORK USING MANAGING AS DESIGNING APPROACH: THE VIRTUAL INNOVATION SOCIETY NETWORK CASE
}

\begin{abstract}
The most recent operations and management frameworks in innovation have not been complete to explicit required knowledge to manage the cooperation of its networked open innovation value chain in the knowledge economy and open enterprise. Strategic actors from the Virtual Innovation Society network were interviewed to identify critical semantic parameters that address this issue. As a result, this study suggests the characterization of inter-dependent added-values and its performance metrics, under the "managing as designing" approach, as input for managing the externalities, the integration of the articulation between business operations, strategy and information technology, and waste of innovation. In this context, the identification of the main managerial indicators for future command and control of existing innovation network operations under the "managing as designing" approach becomes a new challenge for future research.
\end{abstract}

Keywords: Managing as Designing; Innovation Management; Network Managament; Operations Management; Virtual Networks.

\footnotetext{
${ }^{1}$ Pos Doctoral Researcher at Embrapa Instrumentação (CNPDIA), São Carlos-SP (Brazil). [cristiane.gattaz@gmail.com]

${ }^{2}$ Researcher at Embrapa Instrumentação (CNPDIA), São Carlos-SP (Brazil). [paulo.cruvinel@embrapa.br]

${ }^{3}$ Professor of the Postgraduate Program in Administration at University Nove de Julho (UNINOVE), São PauloSP (Brazil). [piscopomr@yahoo.com]
} 


\section{INTRODUCTION}

Inspired by the movement of innovation and the rapid changes in the knowledge economy, organizations have been going through a new wave of revolutionary operations and management strategy transformation with foreseen environmental impacts.

Following one of the finest examples of a well-developed theory of the design attitude for managers (Simon, 1996), design thinking has been evident in the history of management methods and organization structures and processes, especially as they relate to ensuring control of an organization (Gattaz Sobrinho, 2000; Gattaz, 2001; Schouten and Van Beers, 2008; Di Serio, 2009). Design thinking is also at the core of effective strategy development, organizational change, and constraint-sensitive problem solving (Boland and Collopy, 2004; Boland et al., 2008). Since then, the use of models in decision and design has evolved.

\subsection{Inter-organizational Relationship Frameworks}

From 1920 to 1980, global organizations have operated through functional silos (De Sordi, 2005) after the introduction of efficiency, specialization and process measurement concepts by Frederick Taylor. The inter-organizational relationship was highly verticalized and was represented by individual functions as shown in the first model of Figure 1 shown below (Pall, 2000). In this case, there was an increment of the value chain costs within the innovation processes and information technology was still a poor instrument for communication. 


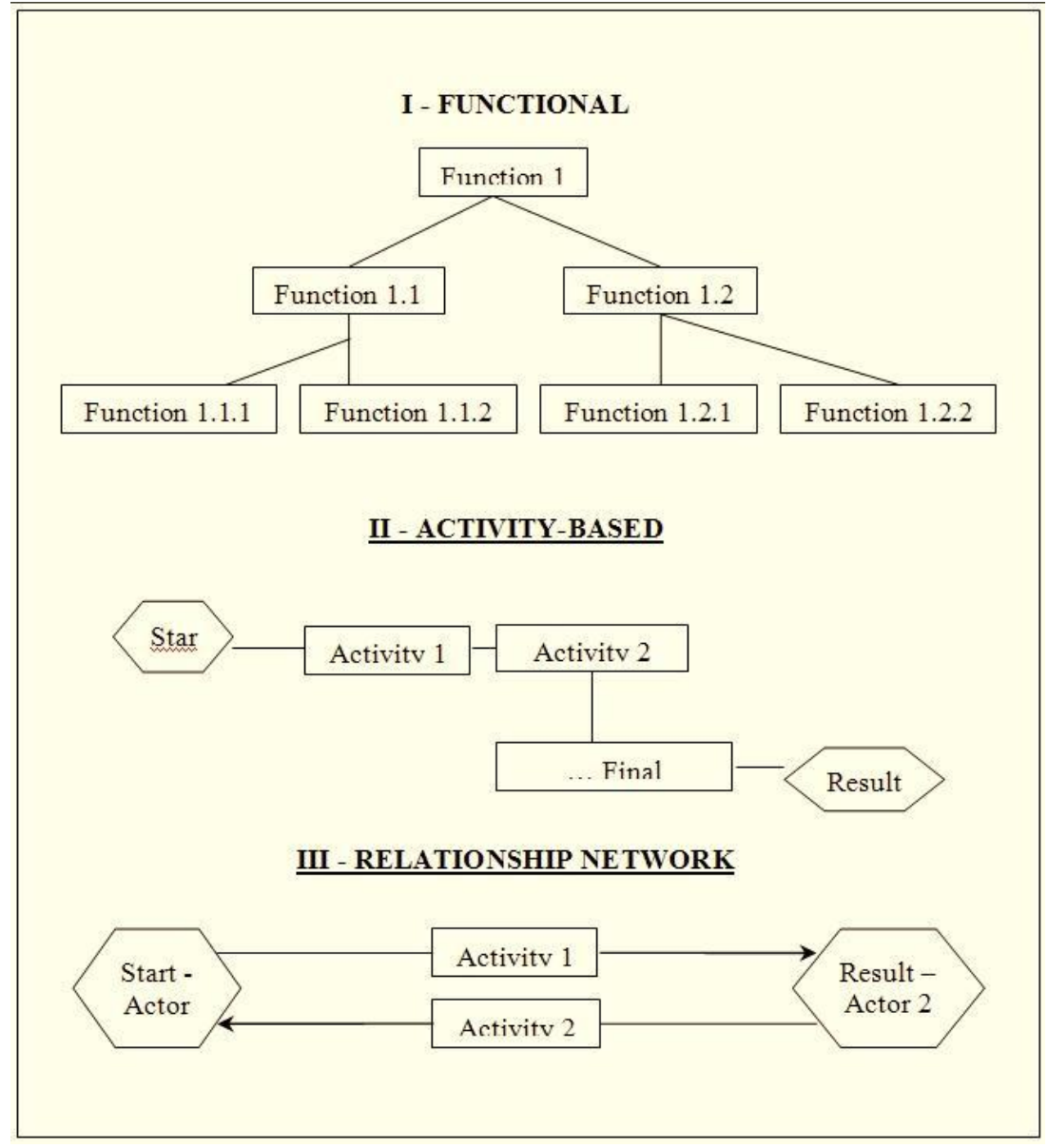

Figure 1. Relationship frameworks

In 1980, businesses began to introduce the total quality aspect into their operations. Business structures of this period moved from a verticalized model to a hybrid (vertical-horizontal) model. From this moment on, not only functions but also competencies and business processes became decisive for innovation operation. Also, innovation relationships within this matrix were represented by an activitybased model as shown in the second framework of Figure 1 (Pall, 2000). In this case, the increment of the value chain costs within innovation processes continued but information technology became more important for communication after introducing the Internet into the market.
However, interaction problems among the organizational areas remained and customer's needs were changing continuously. Clayton Christensen points out in World Innovation 2011 summary that companies fail because they fail to take risks with disruptive innovation and fail to connect with real customers needs ${ }^{4}$. Both contexts highly evolved the complexity of internal and external business innovation environments (systems). The innovation architecture had to be more user driven, flexible, agile and "open" (use of external and internal ideas and paths to market) to create new business competitive advantages through economic sustainability (Chesbrough et

\footnotetext{
${ }^{4}$ World Innovation Forum Summary 2011
} 
al., 2006; Selig et al., 2008, De Moor et al., 2010). For the survival of organizations in an adaptive complex system, the restructuring of their innovation operations based on the revolutionary open innovation and cooperative-oriented network paradigms became decisive since 1990 (Chesbrough et al., 2006; De Sordi, 2005; Polenske, 2004; Sacomano and Truzzi, 2005; Amato Neto, 2005). Large companies have been restructured following the decisions of vertical disintegration, focus, outsourcing, flattening and partnership (Amato Neto, 2005). The network model is represented by nodes (actors) and connections (activities and social technologies) as shown in the 3rd framework of Figure 1 (Costa, 2005; Teixeira, 2005). The formalization of operations in the interaction between the organizations has become a challenge for management (Polenske, 2004; CICI, 2012). Recent trends in large companies indicate that they are more concerned about protecting their internal intellectual property and miss out on opportunities on enabling new technologies with more effective collaboration in the vertical and horizontal model described earlier.

More recently, the study of a particular social network has been applied primarily in understanding the complexity of socio-economic, informational, physical, and symbolic systems. Examples include knowledge sharing, humanmachine and human-human interactions, business orchestra, operations interactions, economic markets, communities of interest, local development, among many others.
The understanding of many of these complex systems has been applied in the organizational field to contribute initially to the qualification of industries to innovate their business processes efficiently and effectively (Castells, 2007; Shirky, 2008; Ribeiro-Soriano and Urbano, 2009; Newman et al, 2006; Nash, 1950a and b; Mitchell, 2006; Martin and Eisenhardt, 2010; Humphrey and Schmitz, 2008). In addition, the social network architectures have facilitated the identification of managerial requirements for improving the sustainability performance of innovation and developing a network management model (Sull and Spinosa, 2007; Roloff, 2008; Henneberg, 2010; Bubenko, 2001; Teixeira, 2005; Nidumolu et al., 2009).

\subsection{The Science, Technology and Innovation Strategy}

The adaptation of innovation operations and strategies has been evolving along with the market dynamics with foreseen economic, technological and social consequences of enormous impact. For the Science, Technology and Innovation $(\mathrm{S}, \mathrm{T} \& \mathrm{I})$ programs, with respect to quality of life, the interest resides in technological innovations capable of significantly contributing to the advance of the S,T\&I sector and generating products and services applicable to its programs (NAS, 2008).

According to the Board of Directors of the Virtual Innovation Society network, the S,T\&I sector is not aiming a complete technological autonomy in all the production chain but is interested in choosing and treading a path, which 
permits the optimization of gains, the added-value, the competitiveness, the positioning in the value chain and the power of swap as a result of its investments and research efforts and in new undertakings (Boland et al., 2007; Reena, 2007). Also, the VIS professionals mentioned that this path should be encountered considering that when the country aims a stronger relationship with university centers of research in the S,T\&I program, national researches in the "quality of life" area are presented in an articulated form in research networks (Knobel, 2004; Andrade, 2004) and consequently takes further coordinated actions. Meanwhile, there are serious gaps in the business sector for the generation of aimed technological innovations and its introduction into products.

According to prospective studies, if some of the "quality of life" applications are forecasted to become effective in a short term ( 0 to 10 years) others will only happen in a mid term (10 to 20 years) or a long term (more than 20 years), having high-priority technologies in each of these cases (NAS, 2008; OECD, 2009). Therefore, a technological roadmap that covers both mid and short terms is needed. Although this plan aims to establish a productive network which includes $R \& D$ actors, activities and resources, the job of elaborating a roadmap results in an extremely complex path, which will require an instrument in the future that turns viable in real time what was planned and aimed.

Within this context, the VIS organized a roadmap related to the development of emerging technologies for "quality of life" applications by covering the research and business networks. This process has been considered as VIS's strategy for qualifying the S,T\&I sector to reduce the gap between suppliers and demand and improving its competitive potential through open and cooperative innovation and sustainable performance in the internationalization of its products.

In order to accomplish its objective, VIS developed 4 steps into the roadmapping process together with other strategic actors of the network (Nehme et al, 2009):

1) Diagnosis: identify and describe the main contexts involved into the construction of the roadmap.

2) Design: present the contexts' interaction through agents, resources and activities; and built the national and international scenarios of emerging technologies for the S,T\&I sector derived from existing and future opportunities, threats, strengths and weaknesses.

3) Analysis: trace alternative paths for the development of emerging technologies for the S,T\&I sector; consolidate and simulate the collected information.

4) Correction: make new adjustments to the roadmap and conclude the strategy model.

5) Develop incisive innovation thinking to the younger generation.

In the first 2 steps, the managing actors characterized some measures that translate the coordination of the innovation 
value chain for the analysis of the commitment in the network relationships (corporate social responsibility), product quality (ecoefficiency) and business partnerships, aiming to form complex industrial systems in the 3rd step (Selig et al., 2008). Business process modeling methodologies, including strategic planning frameworks (Hakansson and Snehota, 1995; Bubenko et al., 2001; Gudas, 2009), were used as an instrument to develop the roadmap as a communication and strategic model to transform implicit knowledge into explicit knowledge (semantic framework). However, the semantic variables used in the roadmapping process were not enough to respond to questions of impact that results from the conflict between goals. In this sense, the management of the coordination of the innovation value chain of "quality of life" products of the S,T\&I sector was interrupted.

\subsection{Objective}

The present work aims at identifying some critical semantic parameters in the design and analysis strategy of the VIS, using the "managing as designing" approach, that may give continuity to the management of its value chain coordination.

The VIS was chosen as the most relevant case for accomplishing the objective of this work. The core competency of this institution is to contribute to breakthrough innovation in science, technology and education by uniting and "activating" innovation students from all fields of knowledge through a cooperative innovation ecosystem to:

$\checkmark$ Serve the public by funding scientific and technological research and development

$\checkmark$ Serve the public through education

$\checkmark$ Serve the public by contributing to a new body of innovation knowledge to be shared with the public, research organizations, academic institutes, K-12 educators, enterprise businesses, government agencies, and nonprofit organizations

$\checkmark$ Serve historically underrepresented public groups including Texas State Historically

$\checkmark$ Underutilized Business and Women Owned Business

$\checkmark$ Foster empathy and deep, contextual understanding of challenges facing our local and global communities

$\checkmark$ Promote innovation as a scientific field of knowledge and profession

$\checkmark$ Transfer knowledge across all fields of knowledge (science, mathematics, engineering, design, Information Technology, communications, business, history, arts, humanities)

$\checkmark$ Leverage trans-discipline and professional domain expertise.

Based on the case study research methodology, this work analyzes the semantics of the inter-organizational network framework of the VIS operations strategy for reducing the gap between the development and absorption of "quality of life" applications.

The object of study of this work does not address which indicators for the command and control of networking 
operations are necessary into the relationship structure.

This paper is organized into the following 5 sections. The following (2nd ) section presents the business process semantic variables used to design and analyze social network operations, based on literature, in the context of "managing as designing" approach. The 3rd section presents the applied research methodology.

\section{MANAGING AS DESIGNING COMPLEX ORGANIZATIONAL NETWORKS}

The organizational development of a given network and the improvement of its quality have involved the management of changes under the intuitive and collaborative approaches (Matzler et al., 2007; Fisser; Browaeys, 2010; Gattaz, 2010), toward problem solving (Roloff, 2008), according to the main fundamentals that define the management approach with decision making known as Managing as Designing as follows (Boland; Collopy, 2004; Boland et al., 2008):

$\checkmark \quad$ Make decisions actively using three essential aspects of decision-making intelligence, design, and choice, inescapably intertwined, and attending the new science of decision to each (mainly to the choice aspect).

$\checkmark$ Produce an expected result even operating in a problem space that has no solid basis for evaluating a solution;

$\checkmark$ Thinking at the heart of the development of effective strategies, organizational change, and problem solving of restriction and sensitive;
The 4th section points out the main research results. Finally, the last section presents the conclusion, which discusses the contribution to Network Operations Management theory and managerial practices and suggests some research challenges for future studies.

$\checkmark$ The innovative methods of collaboration between functional, disciplinary and organizational borders are essential to the design of new products and processes for success. Good dialogue and persuasive arguments, along with the physical movement of manufactured products, contribute to the quality of design ideas; $\checkmark$ The use of various models of a problem and the ideas for your solution can bring different aspects of the problem, different difficulties to be overcome, and a different sense of what a good solution can be-all contributing to a higher quality solution;

$\checkmark$ Drawing, mapping and narrate stories are add-ons to potential models, both physical and analytical, in maintaining an evolutionary understanding of a problem in a more "liquid" state;

$\checkmark$ Search for a good solution while remaining open to "let go" as the emergence of alternatives;

$\checkmark$ A design solution is truly functional if satisfies the design criteria of all who are affected by it, including customers, employees, neighbors, the public and future generations. This transforms the 
criteria of functionality in a relentless pursuit because all the conflicting demands can never be met, and helps keep the approach to a problem in the "liquid" state;

$\checkmark$ Try to solve each problem in a better way than before;

$\checkmark$ Trying to expand the advantageous and innovative use of technologies, including those that are emerging, as well as those that are forgotten;

$\checkmark$ Try to improvise with the available technologies and ideas as a manner of innovation;

$\checkmark$ Trying to reinforce the scope and power of design vocabulary, including the metaphorical images and narratives that are based to inspire the thought;

$\checkmark$ Try to set the highest standards of excellence in design and refuse to resolve unnecessary commitments.

In this context, complex, but flexible and agile inter-organization relationship models in general have been structured using a static representation upon a considerable number of interrelated nodes and connections (Costa, 2005; Teixeira, 2005; Newman, et al., 2006, Mitchell, 2006).

Each node can be considered an individual, a group (enterprise) or a community, which has a specific role toward the objective the network is being developed. Also, these nodes connect to each other through certain relationship models to execute a specific operation. The interaction between these nodes and connections are based on several contexts, either internal or external to the innovation environment, and which are part of the objective strategy in action.
Under the "managing as designing" approach, the design of business processes brought the following significance to the inter-relation between nodes and connections (Hakansson and Snehota, 1995; Bubenko et al., 2001; Gudas, 2009; Gattaz, 2010):

$\checkmark$ Classification, operationalization, prioritization, refinement and correlation of organizational objectives: detail of the highest level of satisfaction of objectives; categorization of goals by origin, stakeholders, function, domain; constraints of higher-level goals to lower-level goals; ranking of goals; collaboration or antagonism between goals.

$\checkmark$ Managing conflicts between objectives: identification, classification and treatment of conflicts between goals. It is the monitoring of known conflicts and record information about these conflicts, such as the circumstances that led to them.

$\checkmark$ Development of business rules: express the concepts involved or related to the implementation of a rule, the processes that support the rule and that are triggered by it.

$\checkmark$ Objectification of information: hierarchical concepts.

$\checkmark$ Decomposition of processes: production of sub-processes.

$\checkmark$ Definition of responsibilities: structuring of organizational functions.

$\checkmark$ Design of information systems: assists in the measurement; operations to create, modify and delete objects and relationships; the preview, search and navigation of objects and relationships and functionality for data checking and analysis. 
In this sense, the following subsection will present the main parameters from which a cooperation network model is represented dynamically, according to the "managing as designing" approach in order to accomplish the objective of this work.

\subsection{A Semantic for Managing as Designing Organizational Networks}

For the purpose of better communication, the structure of knowledge representation is presented in the form of graphical model, detailed and unambiguous, consolidating the different perceptions of the real world. The models can be classified into three types according to the paradigms of hierarchical decomposition, product evolution and decision: activity-based model, product- based model and decision-based model (include both activity and product-based models). The latter has been a reference approach in the various existing methods of organizational modeling heavily used in the analysis, understanding, development and documentation of a particular organization (Hakansson and Snehota, 1995; Bubenko et al., 2001; Gudas, 2009).

The design parameters suggested by several researchers in the field of organizational modeling and social network analysis, in the context of "managing as designing" approach, are consolidated into the following high-level parameters shown on table 1 (Hakansson and Snehota, 1995; Bubenko et al., 2001; Gudas,

2009).

\begin{tabular}{|c|c|}
\hline Parameters & Definition \\
\hline Objective & $\begin{array}{l}\text { Express a set of measurable states and reaches general } \\
\text { views or directions. Also understood as intention, need, } \\
\text { requirement, desired state. }\end{array}$ \\
\hline Problem & $\begin{array}{l}\text { Express that the environment is or may become an } \\
\text { undesirable state of issues that must be met and that } \\
\text { hinder the achievement of goals. It can be treated in two } \\
\text { types: threat and weakness. }\end{array}$ \\
\hline Cause & Explanation or reason for the problem. \\
\hline Obstacle & $\begin{array}{l}\text { Express business constraints, rules, laws, policies from } \\
\text { the outside world that affect components and connections } \\
\text { in the business model. }\end{array}$ \\
\hline Opportunity & $\begin{array}{l}\text { Express a state that can be achieved, unlike the goal. It is } \\
\text { a situation to take advantage of and be turned into a goal. }\end{array}$ \\
\hline Derivation Rule & Situation attributed to a source. \\
\hline Event-action Rule & $\begin{array}{l}\text { Conditions or preconditions that must be satisfied before } \\
\text { the execution of some activity. }\end{array}$ \\
\hline Constraint & $\begin{array}{l}\text { Demonstrates a concern for the integrity of the } \\
\text { information structure of the components. }\end{array}$ \\
\hline Process & $\begin{array}{l}\text { Set of activities that consume inputs and produces } \\
\text { outputs in terms of information and/or material resources; } \\
\text { are controlled by a set of rules indicating how to produce } \\
\text { the outputs; are related to the model of actors and } \\
\text { resources (performers or guardians); when implemented, } \\
\text { consume a finite amount of resources and time in a given } \\
\text { instance. }\end{array}$ \\
\hline External Process & $\begin{array}{l}\text { Set of activities that are outside the scope of the area of } \\
\text { the organization's activities, communicate with processes } \\
\text { or activities in the area of the problem domain. }\end{array}$ \\
\hline
\end{tabular}




\begin{tabular}{|c|c|}
\hline Information or Set of Materials & $\begin{array}{l}\text { Set of information (concept and attribute) or material sent } \\
\text { from an external process or process to another. }\end{array}$ \\
\hline Actor & $\begin{array}{l}\text { Can be an individual or an organizational structure such } \\
\text { as a group, department, division, section, project, time, } \\
\text { status, etc. }\end{array}$ \\
\hline Non-human Resource & $\begin{array}{l}\text { Type or machine, system of various types, equipment, } \\
\text { among others. }\end{array}$ \\
\hline Role & $\begin{array}{l}\text { Run processes and be responsible in carrying out } \\
\text { procedures and set and achieve goals. }\end{array}$ \\
\hline Information System Objective & $\begin{array}{l}\text { Express a high degree of goals with respect to the } \\
\text { information system or subsystems or components. Can be } \\
\text { expressed by properties, targets, visions, and directions } \\
\text { measurable or not. }\end{array}$ \\
\hline Information System Problem & $\begin{array}{l}\text { Express undesirable states of business, or the } \\
\text { environment, or problematic facts about the current } \\
\text { situation with respect to the information system to be } \\
\text { developed. }\end{array}$ \\
\hline Information System Requirement & $\begin{array}{l}\text { Requirement of a functional or non-functional property } \\
\text { of the innovation system to be developed. Refers to the } \\
\text { components of the process model, actors and resources } \\
\text { and information. }\end{array}$ \\
\hline Connectors “AND"/ “OR" & $\begin{array}{l}\text { Represents the partial and/or total decomposition of the } \\
\text { components for its refinement ("AND"). Presents } \\
\text { alternatives to the refinement of components ("OR"). }\end{array}$ \\
\hline Support Connection & Is seen as "vertical". \\
\hline Conflict Connection & $\begin{array}{l}\text { The conflict can be classified as an "end conflict" (a } \\
\text { desire for two contradictory goals) or a "means conflict" } \\
\text { (more than an actor need to use the same resource to } \\
\text { achieve the same goal). }\end{array}$ \\
\hline Hinder Connection & Displays negative influence between components. \\
\hline Binary Connection & Semantic connection. \\
\hline "IS-A" / "Part-OF" Connection & $\begin{array}{l}\text { A hierarchy of concepts, from general to specific ("IS- } \\
\text { A"). Represents aggregations ("Part-OF"). }\end{array}$ \\
\hline Responsibility Connection & $\begin{array}{l}\text { Can be delegated and transferred among actors. Can be } \\
\text { organizational (decision making) or operational } \\
\text { (execution of tasks). }\end{array}$ \\
\hline Dependence Connection & $\begin{array}{l}\text { An actor depends on another for a resource or business } \\
\text { process. It is a dependency created by the workflow } \\
\text { (resources, outputs, etc.) (Operational) or dependency } \\
\text { created by rules, regulations or relationships of authority } \\
\text { and power (authority). }\end{array}$ \\
\hline
\end{tabular}

Table 1. High level design parameters

The characterization of each of the design parameters was developed through the research methodology described in the next section.

\subsection{The VIS Strategy}

The VIS is cooperating with several actors to organize and optimize a roadmap related to the development of emerging technologies and for "quality of life" applications by covering the research networks and the business sector.

This strategy operation for innovation is composed of five steps, as described in the introduction section of the present paper. Up to this moment, the VIS has accomplished the first step. So this section will only present the existing relationship process and its structure 
elements within the operation of the identification and description of the main contexts within the construction of the roadmap.

\subsection{Network Actors, ICTs, Trust and Environmental Interests of the First Step}

In 2008, leading engineers and scientists of the National Academies identified advances in four critical areas that could improve quality of life around the world: sustainability, health, reducing vulnerability, and improved living. The list of fourteen challenges is as follows (NAS, 2008):

$\checkmark \quad$ Make solar energy affordable

$\checkmark$ Provide energy from fusion

$\checkmark$ Develop carbon sequestration methods

$\checkmark$ Manage the nitrogen cycle

$\checkmark$ Provide access to clean water

$\checkmark$ Restore and improve urban infrastructure

$\checkmark$ Advance health informatics

$\checkmark$ Engineer better medicines

$\checkmark$ Reverse engineer the neural network and the brain

$\checkmark$ Prevent nuclear terror

$\checkmark$ Secure cyberspace $\checkmark$ Enhance virtual reality

$\checkmark$ Advance personalized learning

$\checkmark$ Engineer the tools for scientific discovery

$\checkmark$ Security of smart grid systems

These grand challenges of today are global and cannot be solved by science alone. To solve these complex challenges we need to bring together resources, motivations, and commitments. Solutions to global problems involve science, engineering, technology, and public policy (Petroski, 2010). The VIS believes through the creation of an innovation ecosystem that transcends disciplines, barriers, and borders, with unity of purpose, it can significantly contribute to revolutionary advances needed to meet global challenges. In this context, the VIS strategy brings to the table not references to existing marketing reports nor existing scientific investigations on these challenging disruptive technologies but a platform with engineering and science community on a realistic definition of the problem and methodology to build a small business with bridging the gap between innovation and building the actual product (see

Figure

2). 


\section{VIRTUAL INNOVATION SOCIETY}

Strategy Map

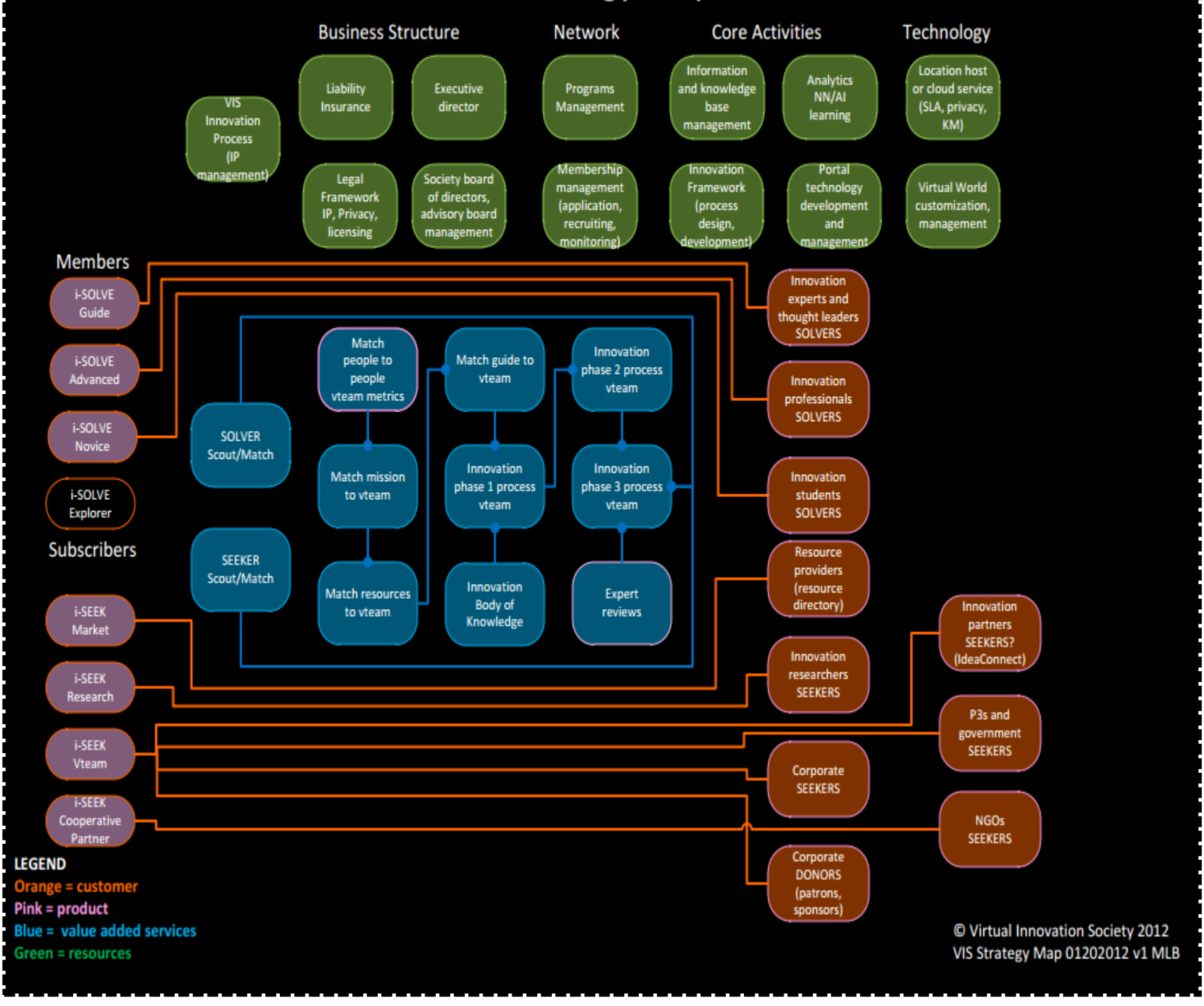

Figure 2. VIS strategy map

Toyota Way $^{5}$ by Prof. Jeffrey Likers illustrates that $80 \%$ of product introduction is planning and $20 \%$ is innovation. Planning for Innovation in an open platform is an important component for technology identification and implementation.

\footnotetext{
${ }^{5}$ The Toyota Way -Professor Jeffrey Likers
}

Engineers have long been involved in innovation and indeed a key differentiator of the VIS lies in engineering and technology management leadership and the inclusion of systems engineering approach to developing solutions to complex problems. Engineers deeply study complex problems and then conceptualize and design many functional 
solutions that include analysis of critical specifications, costs estimates, and performance controls. Integrative solutions that include technology innovations almost always involve human experience. Technology innovations are not purely rational or purely functional these innovations are as much creative art as they are science.

Engineers have always pushed the limits of possible. The VIS is leveraging engineering concepts to build innovation systems, processes, practices, and methodologies to be shared, practiced, applied, and taught to everyone. This seems to be a critical success factor to any innovation program. By "unbinding" innovation activities from purely science, or purely research and development, the VIS is opening up innovation to all people.

Foundation members value the organization's creed and are dedicated to contributing to the organizations vision and mission, thus ensuring that the VIS is building an organization comprised of the right resources, motivation, and commitment to develop integrative solutions that advance science and technology needed to meet our global challenges.

This has been a way to contribute to breakthrough innovation (see Figure 3):

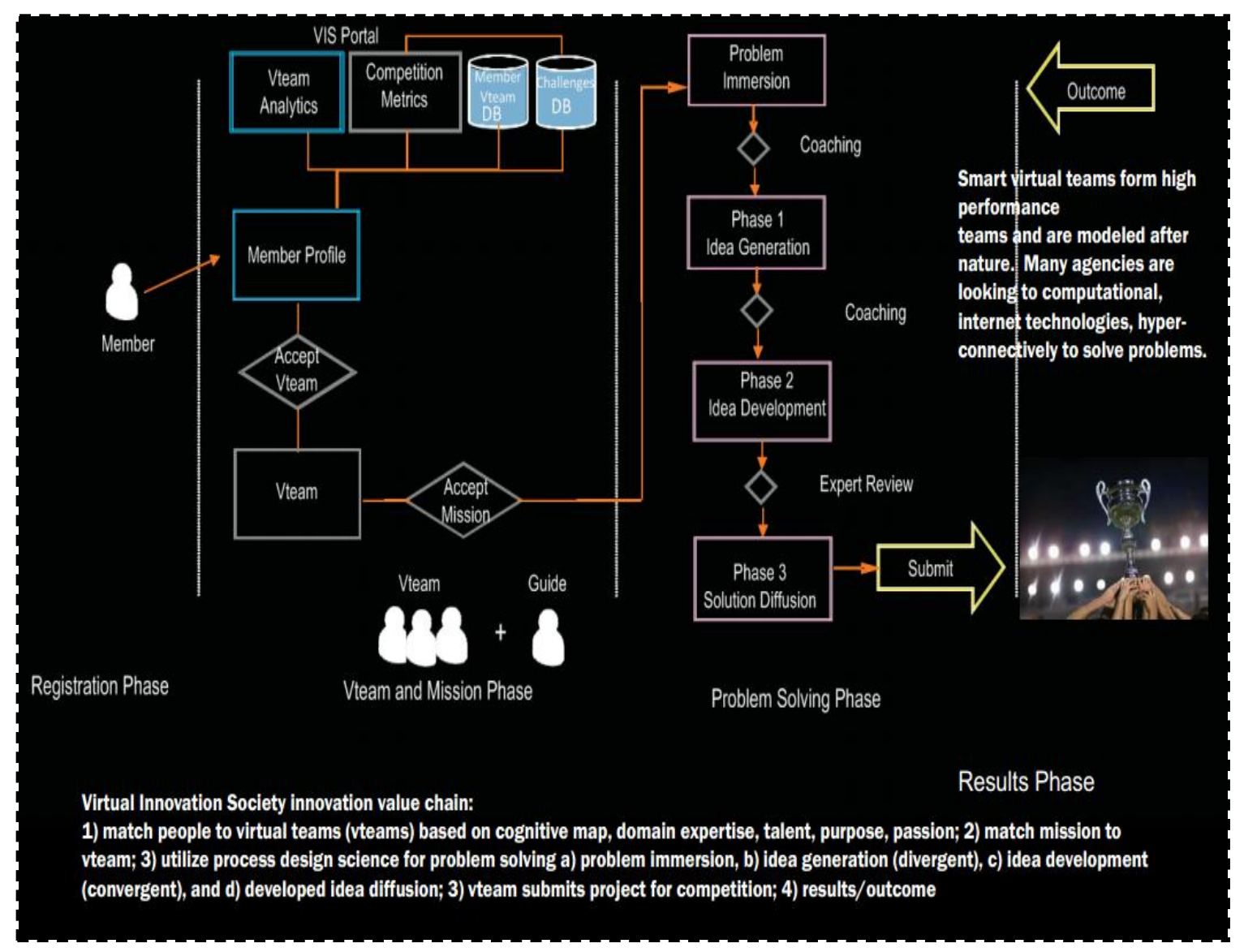

Figure 3. VIS innovation value chain 
In order to provide the greatest positive impact to humanity, the VIS seeks to unite innovators from all fields of knowledge, across boundaries and barriers, and serve as a catalyst for revolutionary advances in scientific and technological research and development, and enhanced education programs involving innovation, creativity, and free enterprise.

The VIS is a 501(c)(3) nonprofit corporation certified in the state of Texas. The corporation is legally governed by the Board of Directors. The

\subsection{Relationship Process}

Function and activity-based forms of relationship process representations have been used during the design and implementation of the VIS strategy activities for innovation. The functionbased form, as shown in Figure 1.1, has been used to represent the hierarchy among the actors, and the activity-based form, as shown in Figures 1.2 and 4, has

\section{RESEARCH METHODOLOGY}

The methodological framework is based on a unique case study supported by data collection techniques involving a strategic area of one of the most important groups of the S,T\&I chain, which greatly impacts on competition of the industry and is responsible for the promotion and management of research and innovation activities among all network actors: the VIS.

According to Yin (2005), the case study method has the main characteristic fact of being generalized to theoretical propositions, and not to populations and universes. The generalization to the
Society is board governed but member driven. While the members do not have legal voting rights, they are highly valued and are engaged to contribute to the development and growth of the VIS. Through membership dues, members help fund the organization. The cornerstone of the Society is contribution and cooperation of its members.

The structure elements can be seen in Figures 2 and 3 above and the next subsection will present the link among the elements.

been used to represent the actors related to the design of the project, the organization and execution of the first meeting to accomplish the first step of the project. The connection among the actors has been represented as shown in Figure 1.3. Each actor connects to the other according to its role and its responsibilities through their hybrid mean of communication and personal interests. The VIS strategy map is represented in Figure 2.

theoretical proposition is exactly the subject intended by the work, which turns the case study into the ideal instrument to reach the objective.

A detailed semi-structuredquestionnaire was created and applied to the Board of Directors of the VIS and to its suppliers related to the development of the first step of the strategy process, described in the previous section. Also, complementary data was collected by observing closely the execution of the first step of VIS's strategy in a meeting.

The main researched subject was to describe the elements of the interorganizational relationship process of VIS's strategy, under the approach of 
"managing as designing", for reducing the gap between supplies and demands related to a specific high technology to identify some operational critical factors. The reduction of this gap enables many institutions of the S,T\&I sector to be capable of innovating efficiently and effectively in an environment with continued unexpected events. The key questions used in the interviews addressed the following elements discussed in section 2 for the design of the $1^{\text {st }}$ step of the VIS's strategy, as for instance:

Which institutional role of the actors were involved in identifying the main goals for reducing the gap between supplies and demands related to a specific high technology for competition: VIS's strategy process suppliers (enterprises) and clients (group of individuals) related to "quality of life" technologies;

$\checkmark \quad$ Which ICTs were used between those actors: virtual and non-virtual relationships;

$\checkmark \quad$ Which governance elements (rules) were used to reduce conflicts and, consequently, transaction costs; and,

$\checkmark \quad$ Which environmental interests from which cooperation among those actors were considered in the relationship: culture of all actors, including the VIS culture and its implications.

The information obtained through interviews with VIS and its strategy operation suppliers were later grouped together and organized using the logical structure of cooperation networks to redefine the interaction and articulation between all actors aimed to guaranty the necessary conditions for qualifying the institutions involved for the effective and efficient execution of its innovation operations for competitiveness.

\section{RESEARCH RESULTS}

According to the "managing as designing" approach, the described semantic parameters of the innovation roadmap resulted in a static representation of the VIS networked operations. A big picture of "how" innovation works and "why" was described. However, the findings encountered from the VIS's roadmapping process brought the following gaps critical for the analysis of its operations and management strategy:

$\checkmark$ The expected results and addedvalues that can be derived from the qualified objectives of the VIS strategy are not explicit. In this case, the externalities of collective actions and the integration of the articulation between VIS's strategy (derived from objectives), its operations and information technology (actual results) cannot be measured and therefore analyzed.

$\checkmark$ There is no quantitative information to qualify and analyze decisive performance factors of sustainability of collective actions such as the reduction of waste and value chain costs.

$\checkmark$ There is a need to approximate the described findings and VIS's interest in choosing and treading a path which permits the optimization of gains, the added-value, the competitiveness, the positioning in the value chain and the power of swap as a result of its investments and research efforts and in new undertakings.

This demand requires new and critical metrics on the ontology designed for the modeling of business processes 
under the "managing as designing" approach used for organizational development and analysis of sustainable performance for the identification and management of externalities, waste and value chain costs; and the integration of the articulation between business strategy, operations and IT.

\section{CONCLUSION AND FINAL CONSIDERATIONS}

Even though the diagnosis phase of the VIS's strategy development was successful, the need of new metrics for analyzing the strategy hindered the management process. For instance, metrics that represents the comparison between real and expected knowledge sharing; the specification of real need of humanmachine and human-human interactions; the references that guide the business orchestra; the interdependence of operations; the identification of the need of communities of interest; the identification of impacts of innovation on local development; the contribution of technological innovations to the S,T\&I advance and generation of products and services applicable to its programs could enable the management of VIS's strategy.

Also, the sustainability of the open innovation process is usually interpreted through the study of impacts according to the main domains of interest (Selig et al., 2008): social, economic, ecologic, space and culture. Businesses have implemented the sustainability processes through 5 stages (Nidumolu, 2009): viewing compliance as opportunity, making value chains sustainable, designing sustainable products and services, developing new business models. For this, the interpretation of the solution brought through collective actions and its interdependence in the innovation process become decisive. So the VIS's process of qualifying itself and involved actors (industry) to innovate their business processes with higher performance level, under the approach of "managing as designing" should be more complete.

Business process modeling methodologies are still not sufficient to explicit knowledge for managing as designing innovation network operations. The effort of building the suggested metrics not only meets VIS's goals but also can result in a new network management ontology that can better explicit the coordination of innovation value chains of other economic sectors.

The identification, description and representation of the objective(s) of each connection (relationship transaction) and all its structure elements involved through supplied results, as shown in Figure 4, are relevant critical factors to better organize the VIS's strategy relationship operation and accomplish its strategic goals rapidly, efficiently and effectively. 


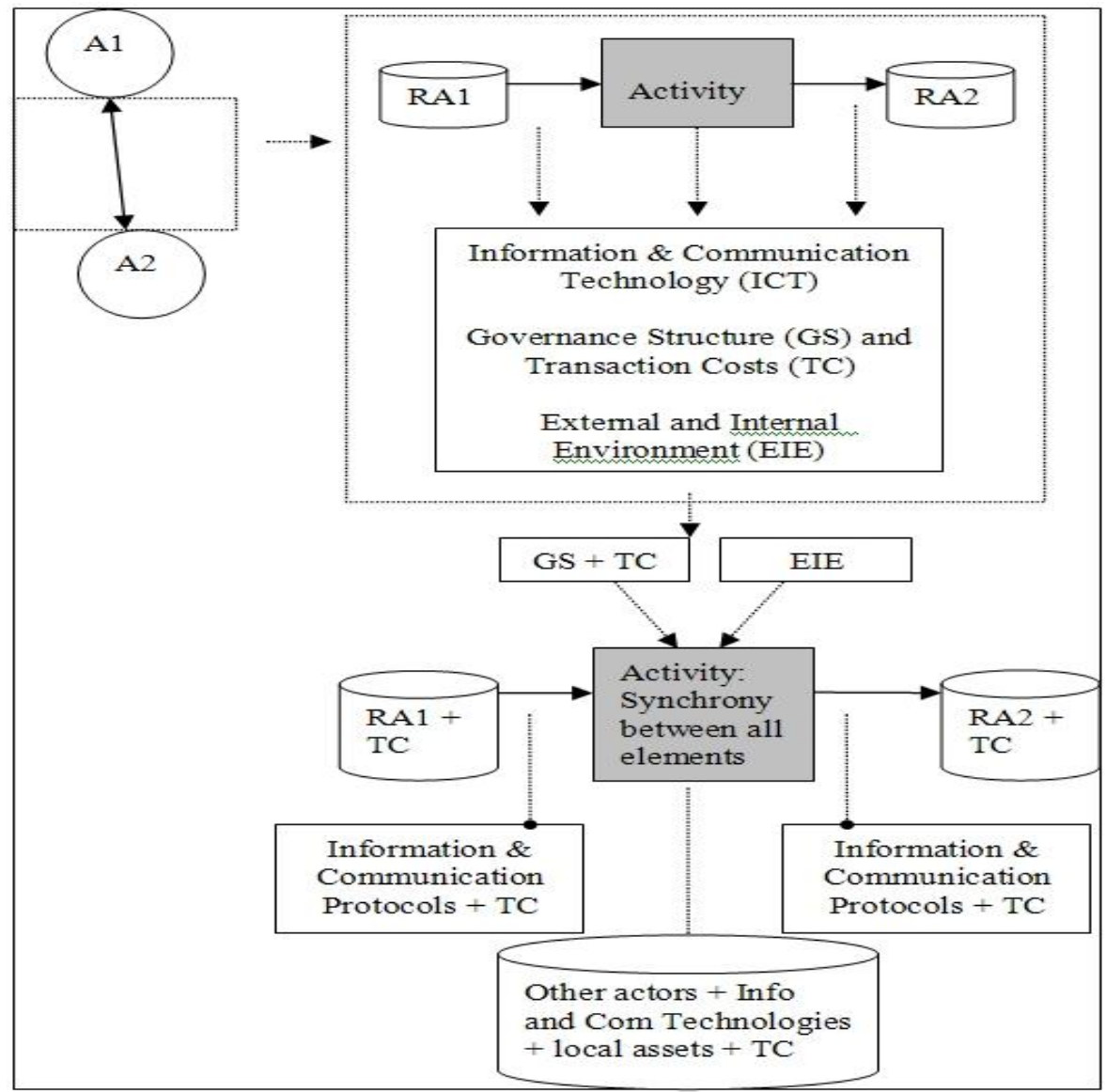

Figure 4. Value-added-based transaction

It provides sufficient means for (Gattaz Sobrinho, 2000):

$\checkmark$ defining what are the required transaction elements to achieve the predefined VIS's strategy objectives;

$\checkmark$ identifying relationship wastes, risks and productivity through network simulation;

$\checkmark$ identifying and developing new technological interfaces;

$\checkmark$ identifying the need of new network actors (roles) during the relationship operation, and

$\checkmark$ identifying the need of new legal policies and technological infrastructure during the relationship operation.

Once the above aspects are accomplished, the value-added-based relationship model of the VIS strategy process may provide conditions for increasing the flexibility of its operation and the speed of reaching its goals effectively by:

$\checkmark$ improving its governance relationship structure or, in other words, solving fewer conflicts among the network actors;

$\checkmark$ reducing negotiation time;

$\checkmark$ reducing information search time, and;

$\checkmark$ reducing transaction costs in general.

An organized, effective and efficient relationship operation framework also facilitates the identification of managerial indicators for future operation 
command and control. So the VIS may rapidly develop the necessary inputs for managing the relationship operation of its strategy.

Also, it stimulates further changes in the governmental, academic and industrial environments (external and internal network environment) of the innovation context through the proposal of new policies and programs for innovation activities development; technology $\mathrm{R} \& \mathrm{D}$ needs; and financial resources for new investments. Consequently, the S,T\&I sector may achieve additional and unexpected competitive advantages.

Therefore, in this case, a valueadded-based network framework that best explicit the VIS's strategy main relationship elements and objectives presented earlier in this article are primary for the effectiveness and efficiency of managing as designing innovation relationship operations.

This work suggests detailing the value-added-based relationship framework and applying it to other sectors. Also, another research challenge is to identify from this framework the main managerial indicators for future command and control of existing innovation network operations.

\section{ACKNOWLEDGMENTS}

The authors would like to thank the Virtual Innovation Society for giving the opportunity for this research and Fapesp for financing this opportunity through the process number 2011/21548-9. 


\section{REFERENCES}

Amato Neto, J. (Org.). (2005). Redes entre organizações: Domínio do conhecimento e da eficácia operacional. São Paulo, SP: Atlas.

Andrade, M. S. (2004). Parcerias estratégicas em nanotecnologia: A experiência da Fundação Centro Tecnológico de Minas Gerais. Revista Parcerias Estratégicas,18, pp. 61-73.

Boland Jr., R.J. \& Collopy, F. (2004). Managing as designing. Palo Alto, California: Stanford University Press.

Boland Jr., R.J., Collopy, F., Lyytinen, K. \& Yoo, Y. (2008). Managing as designing: Lessons for organization leaders from the design practice of Frank O. Gehry. Design Issues, 24, pp. 10-25.

Boland Jr., R.J., Lyytinen, K. \& Yoo, Y. (2007). Wakes of innovation in project networks: The case of digital 3-D representations in architecture, engineering, and construction. Organization Science, 18, pp. 632-647.

Bubenko Jr., J.; Persson, A. \& Stirna, J. (2001). EKD: User guide. Stockholm, Sweden: Kista, Dept. of Computer an Systems Science, Royal Institute of Technology (KTH) and Stockholm University.

Castells, M. (2007). A sociedade em rede. São Paulo, SP: Paz e Terra.

Chesbrough, H., Vanhaverbeke, W. \& West, J. (2006). Open innovation: Researching a new paradigm. Oxford, UK: Oxford University Press.

Conferência Internacional de Cidades Inovadoras, http://www.cici2010.org.br/, date of latest access: 24.03.2012.

Costa, L. F. (2005). Redes complexas: Modelagem simples da natureza. Ciência Hoje, 36, pp. 3448.

De Moor, K., Berte, K., De Marez, L., Joseph, W., Deryckere, T. \& Martens, L. (2010). Userdriven innovation? Challenges of user involvement in future technology analysis. Science and Public Policy, 37, pp. 51-61.

De Sordi, J. O. (2005). Gestão por processos: Uma abordagem da moderna administração. São Paulo, SP: Saraiva.
Di Serio, L. C. (Org.). (2009). Estratégia $e$ competitividade empresarial: Inovação $e$ criação de valor. São Paulo: Saraiva.

Fisser, S.; \& Browaeys, M.J. (2010). Team learning on the edge of chaos. Learning Organization, 17 , pp. 58-68.

Gattaz, C. C. (2001). Brincando de Processo: Um método de capacitação na metodologia de processo. Available in: <http://www.labp3.net>. Accessed in March 1st 2012.

Gattaz, C. C. (2010). Um modelo de referência de formação e gestão de redes organizacionais: $O$ caso do sistema de C,T\&I do setor aeroespacial brasileiro. São Paulo, SP: University of São Paulo.

Gattaz Sobrinho, F. (2000). Processo: A máquina contextual nos negócios. Available in: $<$ http://www.labp3.net>. Accessed in March 1st 2012.

Gudas, S. (2009). Enterprise knowledge modelling: Domains and aspects. Technological and Economic Development of Economy, 15, pp. 281-293.

Hakansson, H. \& Snehota, I. (1995). Developing relationships in business networks. London, UK: Routledge.

Henneberg, S. C.; Naudé, P. \& Mouzas, S. (2010). Sense-making and management in business networks: Some observations, considerations, and a research agenda. Industrial Marketing Management, 39, pp. 355-360.

Herbert, S.A. (1996). The sciences of the artificial. Cambridge, Massachusetts: MIT Press.

Humphrey, J. \& Schmitz, H. (2001). Governance in global value chains. IDS Bulletin, 32, pp. 19-23.

Knobel, M. (2004). Nanoredes. Revista Parcerias Estratégicas, 18, pp. 99-105.

Matzler, K.; Bailom, F. \& Mooradian, T.A. (2007). Intuitive decision making. MIT Sloan Management Review, 49, pp. 13-15.

Martin, J.A. \& Eisenhardt, K.M. (2010). Rewiring: Cross-business-unit collaborations in multibusiness organizations. Academy of Management Journal, 53, pp. 265-301. 
Mitchell, M. (2006). Complex systems: Network thinking. Artificial Intelligence, 170, pp. 11941212.

Nash, J.F. (1950a). Non-cooperative games. PhD.dissertation, Princeton, NJ: Princeton University.

Nash, J.F. (1950b). Equilibrium points in n-person games. Proc. Nat. Acad. Sciences USA., 36, pp. 48-49.

National Academy of Sciences. (2008). Grand challenges for engineering. Arlington, VA: National Science Foundation.

Nehme, C.C; Galvão, A.; Vaz, A.; Coelho, G. \& Fellows Filho, L. (2009). Foresight: Proposta de uma metodologia visando ao fortalecimento da competitividade dos setores industriais brasileiros. Revista Parcerias Estratégicas, 14, 29, pp. 7-20.

Newman, M. E. J.; Barabási, A. L. \& Watts, D. J. (2006). The structure and dynamics of networks. Princeton, NJ: Princeton University Press.

Nidumolu, R., Prahalad, C.K. \& Rangaswami, M.R. (2009). Why sustainability is now the key driver of innovation. Harvard Business Review, 87, pp. 56-64.

Organization for Economic Co-operation and Development. (2009). Policy responses to the economic crisis: Investing in innovation for long-term growth. Washington, DC: OECD.

Pall, G. A. (2000). The process-centered enterprise: The power of commitments. Delray Beach, FL: St. Lucie Press.

Petroski, H. (2010). The essential engineer: Why science alone will not solve our global problems. New York, NY: Alfred A. Knopf.

Polenske, K. R. (2004). Competition, collaboration and cooperation: An uneasy triangle in networks of firms and regions. Regional Studies, 38, pp. 1029-1043.
Reena, J. (2007). A chorus of voices is calling for an end to the hype and a focus on what really drives profitable innovation. Business Week, Issue 4025, special section pp.28-28.

Ribeiro-Soriano, D. \& Urbano, D. (2009). Overview of collaborative entrepreneurship: An integrated approach between business decisions and negotiations. Group Decision and Negotiation, 18, pp. 419-430.

Roloff, J. (2008). Learning from multi-stakeholder networks: Issue-focused stakeholder management. Journal of Business Ethics, 82, pp. 233-250.

Sacomano, M. \& Truzzi, O.M.S. (2005). Governança e análise de redes. In Fusco, J.P.A (Ed.), Redes Produtivas e Cadeias de Fornecimento, Arte \& Ciência, São Paulo, pp. 141-302.

Selig, P.M., Campos, L.M.S. \& Lerípio, A.A. (2008). Gestão ambiental. In Batalha, M.O. (Ed.), Introdução à Engenharia de Produção, Campus Elsevier, pp. 249-272.

Schouten, J. \& Van Beers, W. (2008). Resultoriented management. West Bengal, India: Thema Publishing.

Shirky, C. (2008). Here comes everybody: The power of organizing without organizations. New York, NY: Penguin Press.

Sull, D.N. \& Spinosa, C. (2007). Promise-based management: The essence of execution. Harvard Business Review, 85, pp. 78-86, 141.

Teixeira, F. (Org.). (2005). Gestão de redes de cooperação interempresariais. Pituba, Salvador: Casa da Qualidade.

Liker, J. (2004). The Toyota Way: 14 management principles from the world's great manufacturer. New York, NY: McGraw-Hill

World Innovation Forum, June7-8, 2011 Executive Summary.

Yin, R. (2005). Estudo de caso: Planejamento e método. Porto Alegre, RS: Bookman. 